\title{
Devotional Panels as Sites of Intercultural Exchange
}

\author{
Michele Bacci
}

The use of painted panels as visual counterparts to an individual's or a family group's practice of prayer admittedly was very common in the modern era, yet it would be misleading to consider such a phenomenon as the outcome of a very recent process and as something typical of Western religious experience. Indeed, painted panels of various forms and diminutive dimensions were used in different Christian traditions and in various periods from Late Antiquity through the Late Middle Ages and, in early modern times, they happened to be perceived as objects that could be easily involved in multifarious devotional practices, regardless of their owner's confessional or denominational identity.

This paper aims at raising and discussing the following questions: to what extent, if any, is the involvement of painted panels in individual prayer indebted to previous usages, rooted in the Byzantine and medieval past? To what extent, and on which grounds, did it come to be that in the Late Middle Ages and early modern era Byzantine or Byzantine-like images were perceived as especially suitable for private devotions, and until when did this perception continue to play a role? Which cultural dynamics gave rise, from the fourteenth century onward, to the selective appropriation of morphological, iconographic, and stylistic features associated with both Byzantine and Italian traditions and to their combination in a number of works meant for private or domestic uses? And finally, would it be correct to think of devotional panels, especially those of mixed stylistic character made in Venice and Venetian - or Latin-ruled countries in the Aegean and the Levantine sea, as privileged sites of intercultural exchange?

It is worth stressing that, as recent studies have pointed out, the use of painted panels in private and domestic religious practices has ancient roots. ${ }^{1}$ Contrary

1 The best surveys are Belting H., Bild und Kult. Eine Geschichte des Bildes vor dem Zeitalter der Kunst (Munich: 1990) 103-112; Brenk B., The Apse, the Image and the Icon. An Historical Perspective of the Apse as a Space for Images (Wiesbaden: 2010) 115-130; Sörries R., Das

(C) MICHELE BACCI, $2019 \mid$ DOI:10.1163/9789004375871_013

This is an open access chapter distributed under the terms of the prevailing CC-BY-NC-ND License at the time of publication. 
to what earlier research had assumed, encaustic painting was used in late Antiquity for the making not only of funerary portraits, but also of images of gods and heroes meant to be worshipped in the house lararia: the representation of a third century painter preserved in his tomb found at Cherson, Crimea, shows him working at a number of such images of different shapes, such as clipei and rectangular panels [Fig. 11.1]. ${ }^{2}$ A number of textual hints corroborate the view that the domestic interior was one of the privileged contexts where Christian image worship was developed: here it will be sufficient to mention the well-known story of the newly converted Lykomedes who, according to the second-century apocryphal Gospel of John, set up a painted image of the Apostle in his bedroom and honoured it with wreaths of flowers and candles. ${ }^{3}$ Some third and fourth century authors remark that private houses were replete with images of the new Christian heroes who had undergone martyrdom or lived as ascetics. John Chrysostom, for example, observed that the image of the local martyr Meletios was to be seen almost everywhere in Antioch: namely on seals, rings, fountains, and obviously on the walls of houses. ${ }^{4}$

Meaningfully enough, much of the information we have about such objects comes from texts by churchmen and theologians who wished to manifest their bewilderment at hearing that many people, who claimed to be Christians, were making use of painted portraits of Christ and the most important holy persons and therefore revealed, as the Apostle John reproached Lykomedes, that they were unable to get rid of the pagan habits of their ancestors. And indeed, the practice seems to have become commonplace in the fifth through the seventh centuries, as is witnessed by a number of icons, mostly preserved or found in Egypt, that displayed not only saints, but also deceased bishops and monks. ${ }^{5}$ Indeed, praying in front of images set up in a private space was also distinctive of monastic life. Sources also bear witness to the fact that the

Malibu-Triptychon. Ein Totengedenkbild aus dem Römischen Ägypten und Verwandte Werke der Spätantiken Tafelmalerei (Dettelbach: 2003) 194-197; Matthews Th.F., "Early Icons of the Holy Monastery of Saint Catherine at Sinai", in Nelson R.S. - Collins K.M. (eds.), Holy Image - Hallowed Ground. Icons from Sinai (Los Angeles: 2006) 39-55; Mathews Th., The Dawn of Christian Art in Panel Paintings and Icons (Los Angeles: 2016).

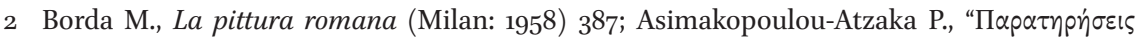

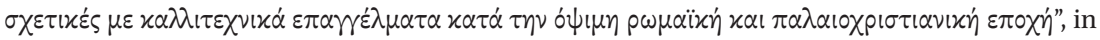

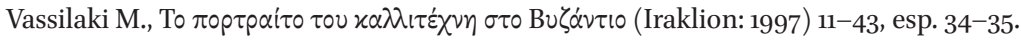

3 Acta Iohannis, chaps 26-28, ed. E. Junod and D. Kaestli (Turnhout: 1983) 176-181.

4 John Chrysostom, Homily in Praise of Archbishop Meletios, ed. J.-P. Migne, Patrologice cursus completus. Series grceca [henceforth PG] (Paris: 1844-1866), vol. L, col. 516.

5 Belting, Bild und Kult 107-110; Sörries, Das Malibu-Triptychon 194-197; and especially the recent study by Thomas F. Mathews, The Dawn of Christian Art in Panel Paintings and Icons (Los Angeles: 2016). 


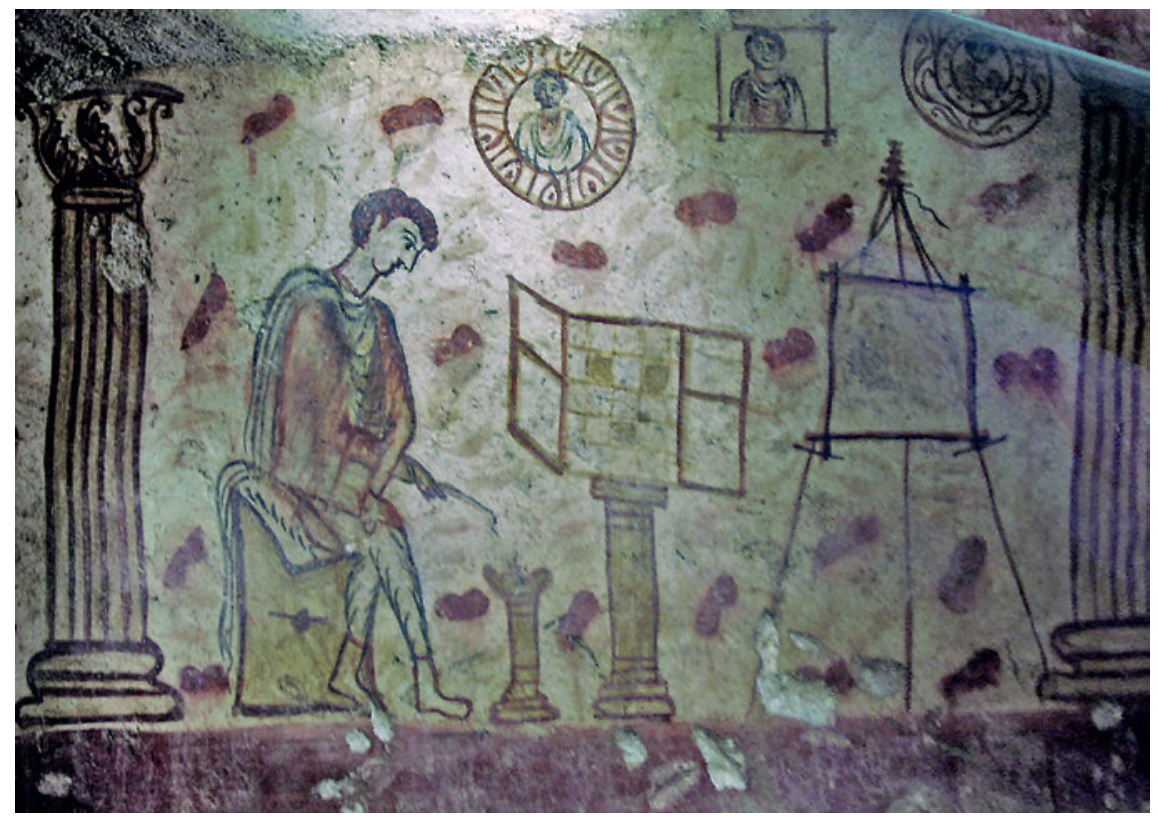

FIGURE 11.1 Representation of a Painter, from a tomb in Cherson, Crimea, 3rd century. Saint Petersburg, The Hermitage Museum PHOTOGRAPH BY THE AUTHOR

introduction of icons into the interior of Eastern Christian churches was partly promoted by individuals, regardless of their status as laypeople or members of the clergy, who aimed at manifesting their piety in terms reminiscent of the devotional experience associated with images in domestic contexts. Icons could be used as signs of thanksgiving for those saints who were supposed to have supplicated - or were encouraged to supplicate - the Lord on behalf of an individual. Even if many such works were made especially to record a donor's act of self-dedication, as is the case with icons depicting bowing persons at the feet of their intercessors, it is likely that images originally meant for a domestic setting may have been used as votive offerings. ${ }^{6}$

The involvement of icons in domestic devotion was perceived as a distinctive, and somewhat blameworthy, aspect of Byzantine religious habits. Leo Tuscus, a native of Pisa who in the 116os and 1170s worked in Constantinople as the Byzantine Emperor's official Latin translator, described the Greek practice of worshipping icons in houses as a most dangerous deviance from the

6 For some early examples preserved on Mount Sinai cf. Weitzmann K., The Monastery of Saint Catherine at Mount Sinai. The Icons, I (From the Sixth to the Tenth Century) (Princeton: 1976) 37-38 no. B. 14 and pl. Xvi; 66-67 no. B.39 and pls. Xxvi, XCIII; cf. Mathews, "Early Icons" $53-54$. 
traditional Christian way of experiencing the sacred as members of the ecclesia, the community of believers:

[...] In their houses they build up small houses (mansiunculas), wherein they put the images of saints, and they manifest to them all possible honours by means of lamps, big candles, and incense. In contrast, they leave empty the congregational churches, built by their fathers, and leave them in poverty. They nearly permit the celebration of the Holy Mass in their bedrooms. ${ }^{7}$

Such mansiunculae are to be understood as the medieval forerunners of the domestic proskynetaria, or small tabernacles, used to house icons throughout Orthodox countries. It is difficult to say what such structures looked like and whether or not it would be misleading to think of them as something like the Russian krasnij ugol, familiar in its usual setting in the corners of living rooms and bedrooms. Some extant objects, such as the diminutive ceramic iconostasis from the tenth century now in the Archaeological Museum at Preslav (Bulgaria), indicate that they could be shaped in such a way as to intentionally remind viewers of pieces of furniture typical of contemporary church interiors [Fig. 11.2]..$^{8}$ In the twelfth century, laypeople experienced the Mass in front of

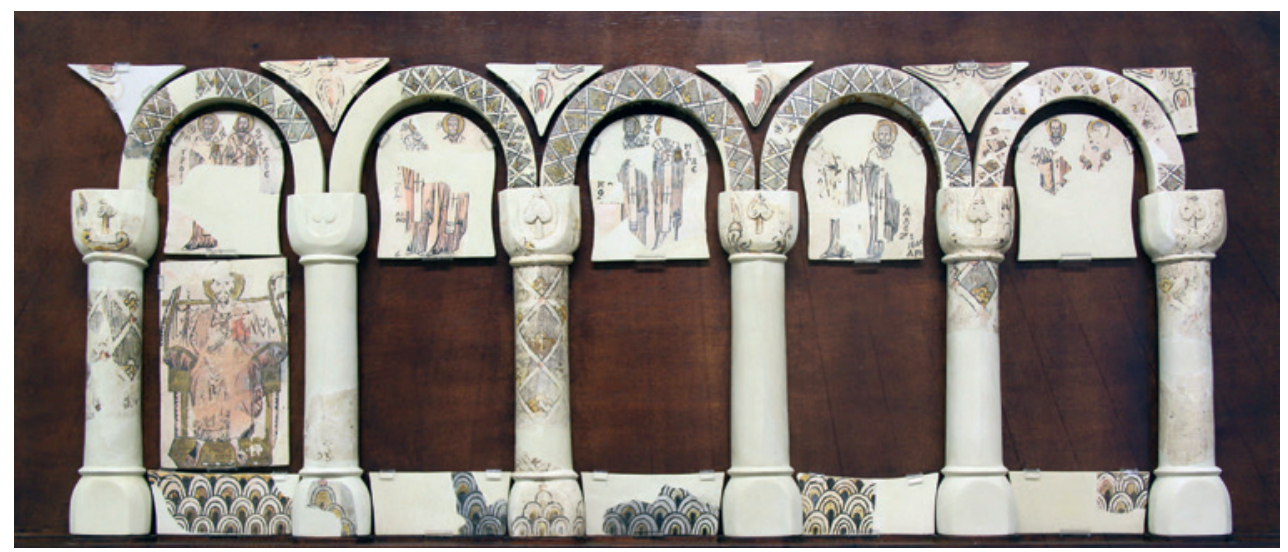

FIgURE 11.2 Ceramic Iconostasis, 1oth century. Preslav (Bulgaria), Archaeological Museum

PHOTOGRAPH BY THE AUTHOR

7 Leo Tuscus, De haeresibus et praevaricationibus Graecorum, ed. J.-P. Migne, PG CXL, coll. 544550, esp. 547 .

8 The basic study is Totev T., The Ceramic Icon in Medieval Bulgaria (Sofia: 1999) 86-89. 
the templon: a marble, wooden, or even metal barrier separating the crowd gathered in the nave from the space reserved for the altar and the officiating clergy. Increasingly frequently, such barriers were used as support for icons, and believers became accustomed to gazing at them during the most solemn moments of the Mass. ${ }^{9}$ By looking at icons set within a miniaturized templon, viewers were able to imaginatively re-enact their experience of the holy liturgy in a space and time other than those of the liturgical rite.

\section{Second Phase: Byzantium to Italy}

In this respect, Leo Tuscus was not totally wrong in assuming that there was a risk of transforming icon devotion in the home into a surrogate of the Mass. Yet, it is striking that this condemnation of Byzantine domestic piety came from the native of an Italian town - Pisa - which stood out for its early and strong interest in making use of religious painted panels as visual supports for individual prayer. The imitation of icons became widespread very early in the Tuscan port, which had strong connections with both Byzantium and the Eastern Mediterranean countries, including the Crusader-ruled SyroPalestinian coast. ${ }^{10}$ Painted images of the Virgin Mary purposely made in the Greek way, that is by reproducing some of their basic morphological, iconographic, and stylistic features, were produced in Pisa from the twelfth century, if the dating proposed for the panel formerly preserved in Santa Chiara and now in the National Museum of San Matteo proves to be correct [Fig. 11.3].11 What is more important, some contemporary texts hint at the imitation not only of forms, but also of some Byzantine devotional practices involving icons, particularly their privileged setting in private, rather than public contexts: for

9 Best survey in Gerstel Sh.E.J (ed.), Thresholds of the Sacred. Architectural, Art Historical, Liturgical, and Theological Perspectives on Religious Screens, East and West (Washington D.C.: 2006).

10 Bacci M., "Pisa bizantina. Alle origini del culto delle icone in Toscana", in Calderoni Masetti A.R. - Dufour Bozzo C. - Wolf G. (eds.), Intorno al Sacro Volto. Genova, Bisanzio e il Mediterraneo (secoli XI-XIV) (Venice: 2007) 63-78.

11 Garrison E.B., Italian Romanesque Panel Painting: An Illustrated Index (Florence 1949), no. 110; Garrison E.B., Early Italian Painting: Selected Studies (London: 1984), I, 259-261; Caleca A., "La pittura medievale in Toscana", in Bertelli C. (ed.), La pittura in Italia: l'Altomedioevo (Milan: 1994) 163-179, esp. 170; Boskovits M., The Origins of Florentine Painting, 1100-1270 (Florence: 1993) 25 fn. 20; Bacci M., "Toscane, Byzance et Levant: pour une histoire dynamique des rapports artistiques méditerranéens au XIIe et XIIIe siècles", in Caillet J.-P. - Joubert F. (eds.), Orient et Occident méditerranéens au XIIIe siècle. Les programmes picturaux (Paris: 2012) 235-256, esp. 240-241. 


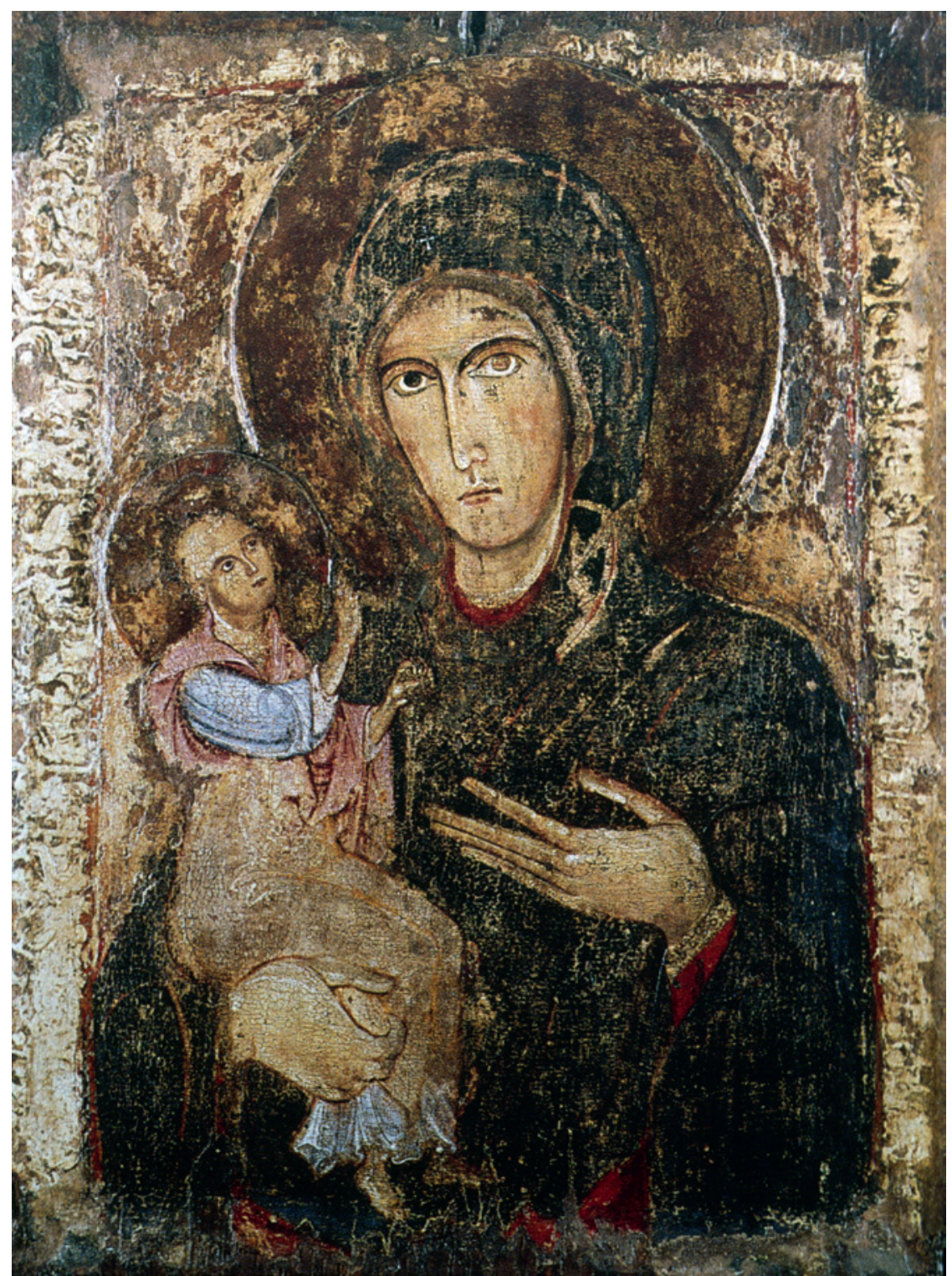

FIGURE 11.3 Madonna di Santa Chiara, painted panel, Pisa, late 12th century. Pisa, National Museum of San Matteo PHOTOGRAPH BY THE AUTHOR 
example, the thirteenth-century life of Saint Bona, a local lay woman, reports that the monks of San Michele degli Scalzi were accustomed to pray and meditate in front of the icons kept in their cells. ${ }^{12}$

The icon-like images painted in Pisa are mainly rectangular-shaped panels of modest size depicting the Virgin Mary. Some of them have a border in relief, either simply gilded or decorated with saintly figures, as in their Eastern models. Certain panels have arched tops which indicate that they were originally part of triptychs. These probably looked much like analogous objects which are known to have circulated widely not only in mainland Byzantium, but also in the Eastern Mediterranean, as a number of comparanda preserved in Saint Catherine's monastery on Mount Sinai seems to indicate. ${ }^{13}$ One such is the much worshipped Madonna di sotto gli organi, a work universally thought to date from around 1200, yet variously described as a Greek or a local Tuscan work [Fig. 11.4].14 Scholarly embarrassment about this panel is itself an indicator of Pisa's deep familiarity with Byzantine icons: whoever painted it, he had a first-hand knowledge of iconographic details alien to Western tradition, such as the diaphanous tunic to be seen on Christ's blessing arm, the accurate rendering of the Child's and his Mother's garments, or the distinctively unnatural proportions of the bodies. The 'Byzantine-ness' of the work is emphasised by the open book bearing a Greek inscription from the Gospel of John (8:12), a detail that is undoubtedly more usual as an attribute of Christ in monumental representations as Pantokrator than of the Child in icons of the Virgin Mary - even if some thirteenth-century parallels from Cyprus are also known. The absence of the standard Greek abbreviations for Mary and Christ should not be regarded as an argument against Byzantine authorship, given that the

12 Life of Saint Bona, ed. G. Zaccagnini, La tradizione agiografica di santa Bona da Pisa (Pisa: 2004) 138.

13 Vokotopoulos P., "Funzioni e tipologia delle icone", in Velmans T. (ed.), Il viaggio dell'icona dalle origini alla caduta di Bisanzio (Milan: 2002) 109-150, esp. 115-119.

14 Garrison E.B., "Post-War Discoveries: Early Italian Painting, III: The Madonna di sotto gli organi", Burlington Magazine 89 (1947) 274-279; Bacci M., "Due tavole della Vergine nella Toscana occidentale del primo Duecento", Annali della Scuola Normale Superiore di Pisa ser. IV, 2 (1997) 36-53; Bacci, "Pisa bizantina" 72; Pace V., "Modelli da Oriente nella pittura duecentesca su tavola in Italia centrale", Mitteilungen des Kunsthistorischen Institutes in Florenz 44 (2000) 19-41; Pace V., "Between East and West", in Vassilaki M., Mother of God: Representations of the Virgin in Byzantine Art (Milan-Athens: 2000) 425-432; Bacci, "Toscane, Byzance et Levant" 242; Weyl Carr A., "Thirteenth-Century Cyprus: Questions of Style", in Caillet - Joubert, Orient et Occident méditerranéens 65-86, esp. 72-74; Folda J., Byzantine Art and Italian Panel Painting. The Virgin and Child Hodegetria and the Art of Chrysography (Cambridge: 2015) 136-137, 331-332. 


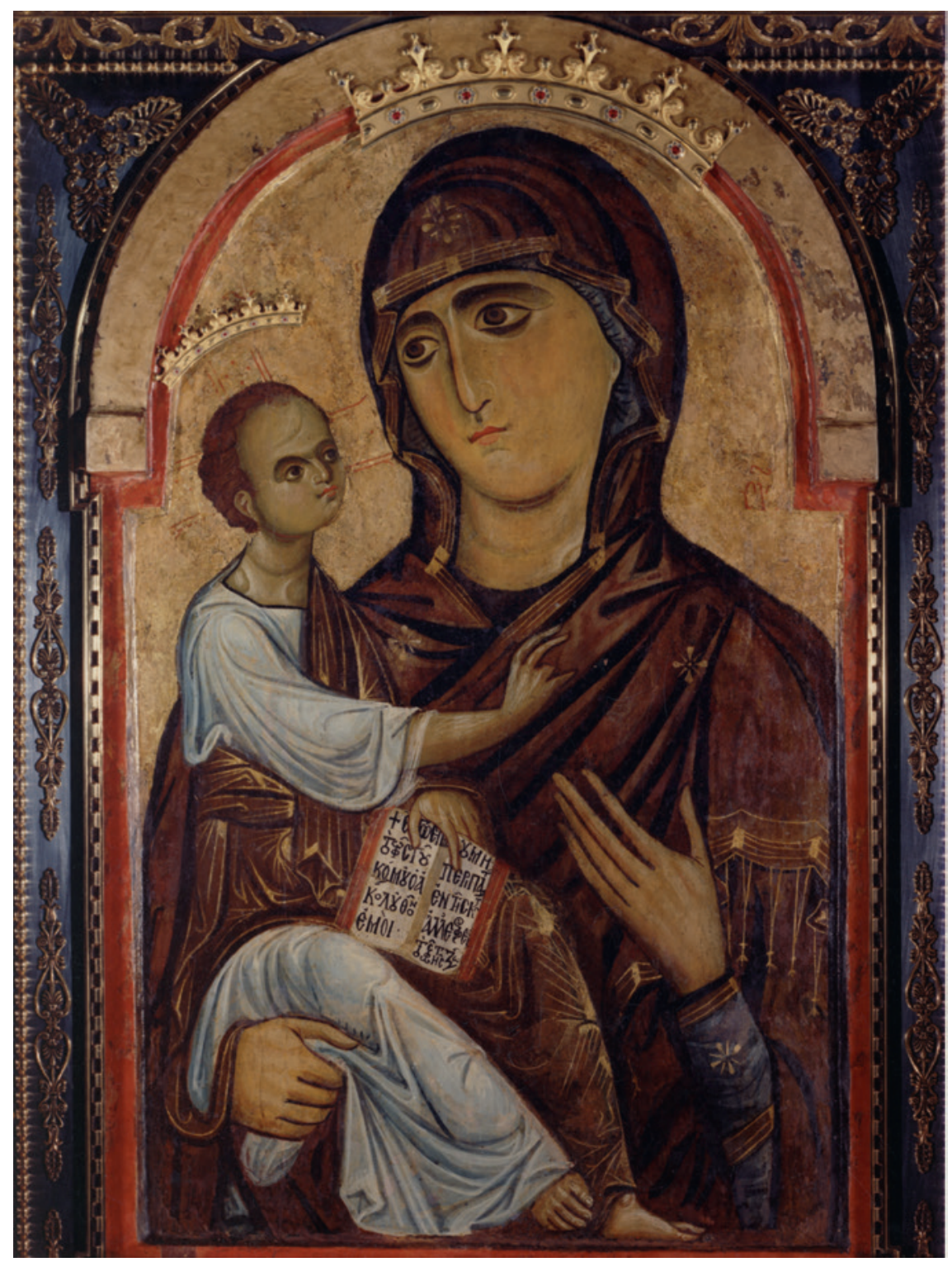

FIGURE 11.4 Madonna di sotto gli organi, icon, ca. 1200. Pisa, Cathedral of Our Lady PHOTOGRAPH BY THE AUTHOR 
background is known to have been thoroughly repainted by the local artist Giovan Battista Tempesti in $1790 .{ }^{15}$

More interesting is the fact that the destination of the work for a domestic setting, which seems to be implied by the fact it was originally part of a triptych, is corroborated by the legends that were recorded on the occasion of its promotion to a public object of worship in the late fifteenth or early sixteenth century. Such stories stated that the icon had long since been preserved in a private setting, the castle of Lombrici, before it was looted by the Pisan army during the war with Lucca in $1225 .{ }^{16}$ In some way, the association of the work with the practice of domestic devotion was still recognised when its final change of status officially took place.

The imitation of icons was certainly stimulated by the perception that Byzantine religious painting was invested with a special authority, associated with its alleged apostolic roots (stemming from archetypal portraits made by Saint Luke and transmitted to the following generations by a chain of uninterrupted replicas). The Evangelist's celebrated works, preserved in Constantinople and Rome, were supposed to convey the exact physiognomic features of Christ and the Virgin Mary and were therefore regarded as historical documents of their appearances, complementing the Holy Scriptures. Luke's Greek identity was also perceived to bear on his skills as artist: painting was definitely described as the Byzantine technique and artistic medium par excellence. ${ }^{17}$ In this respect, the religious worthiness of a painted panel, especially of the Virgin Mary, could sometimes be successfully enhanced by a generic icon-like appearance, such as the representation of a half-length figure, the golden background, or the use of Greek abbreviations, or by the appropriation and reproduction of a more distinctively Greek style - as is made evident by attempts to imitate Byzantine modelling and highlighting devices (for example in Giunta Pisano's works). ${ }^{18}$ Over time certain distinctive features came to be accurately imitated, yet excessively multiplied, as is the case with chrysography, which was often used not so much to highlight parts of the holy

\footnotetext{
15 Bacci, "Due tavole" 38; cf. the misunderstanding in Folda, Byzantine Art 137.

16 As first witnessed in 1528 by Bianco Bianchi, ed. R. Antonelli, Bianco Bianchi cronista del '50o (Lucca: 1995) 93.

17 Bacci M., "L'effige sacra e il suo spettatore", in Castelnuovo E. - Sergi G. (eds.), Arti e storia nel Medioevo. Volume terzo. Del vedere: pubblici, forme e funzioni (Turin: 2004) 199-252, esp. 238-246.

18 Bacci, "Toscane, Byzance et Levant" 243-245.
} 
person's garments, but almost to cover them indistinctly with a wide net of golden filaments. ${ }^{19}$

Yet, in many cases, style - or at least those elements of form that formalistic art history has traditionally perceived as a set of distinctive marks of a specific artistic tradition - did not really matter: forms of both Byzantine and Western origins were often freely selected, combined, and transformed to shape images meant to be efficacious on devotional, rather than mimetic grounds. The connection with Byzantium was especially evident in those compositional and iconographic types that were strongly rooted in the Eastern Christian tradition of icon-painting, such as the Virgin Mary, some apostles or specifically Oriental saints such as Egyptian hermits and desert fathers. Despite the traditional emphasis placed by art history since Vasari on the Byzantine-oriented nature of thirteenth-century Italian painting - the so-called 'maniera greca' - the extent to which the widespread perception of painted panels as icon-like objects implied the appropriation of specifically Greek forms is hard to evaluate. An often quoted passage of a sermon by the Dominican friar Giordano da Rivalto in 1305 bears witness to the authority attributed to Byzantine pictorial tradition, yet it also reveals that the preacher's concept of those 'worship-worthy icons having come in antiquity from Greece' was rather confused. He hints at the pictorial scheme of the Adoration of the Magi as distinct from that of the Nativity and lays emphasis on the Magi's royal status as authoritatively indicated by their representation as kings wearing crowns: he was clearly unable (or unconcerned) to identify such features as alien to Byzantine tradition and typical of Western imagery. ${ }^{20}$

Indeed, it was not before the mid-fifteenth century that the perception of Byzantine style as radically distinct from a Western one was clearly stated in a number of sources. In Cennini's famous characterisation of Giotto's innovative forms as a translation from Greek into Latin the term 'Greek' was used to hint at earlier Tuscan paintings, i.e. at a pictorial tradition which, in Giovanni Boccaccio's words, was considered as a sort of popular or even vulgar art, meant 'rather to tickle the eyes of the ignorant, than to gratify the intellect of

19 Polzer J., "Concerning Chrysography in Dugento Tuscan Painting and the Origin of the Two Washington Madonnas", Arte Medievale ser. IV, 2 (2012) 205-216; Folda, Byzantine Art.

20 Giordano da Rivalto, Sermons Held on the Courtyard of Santa Maria Novella, ed. E. Narducci, Prediche inedite del b. Giordano da Rivalto dell'Ordine de' Predicatori (Bologna: 1867) 170-171. Cf. Cutler A., 'La 'questione bizantina' nella pittura italiana: una visione alternativa della 'maniera greca', in Bertelli C., La pittura in Italia. L'Altomedioevo (Milan: 1994) 335-354; Belting, Bild und Kult 370; Cannon J., Religious Poverty, Visual Riches. Art in the Dominican Churches of Central Italy in the Thirteenth and Fourteenth Centuries (New Haven-London: 2013) 63-64. 
the wise people.' ${ }^{21}$ Thirteenth-century 'maniera greca' panels, with an icon-like appearance and understood as rather basic supports for devotional practice, were contrasted with a new set of forms said to be more fit for more sensitive and cultivated people. Most likely - as art history has normally assumed, even if it is not clearly stated - this was on account of their capacity to imitate nature efficaciously and make visible human emotions. One of the earliest texts where a stricto sensu Byzantine icon is set against a Western painting is the priest Andrea Ingenerio's booklet about a miracle worked by Saint Theodosia in Venice in 1440 . It tells the story of a Venetian lady suffering from a very serious illness who asked one of her acquaintances to bring her an icon of Saint Theodosia from Constantinople. Her husband, disappointed by the awkward appearance of the image and its expensive price, decided to reject it and have another, better painting made by a Venetian artist. This work looked much more appealing to him, but it proved to be completely unable to work any healing. As the lady's health deteriorated, the man finally resolved to buy the icon for double the original price, and she was finally cured. ${ }^{22}$

This story indicates that by this point icons and Venetian paintings were perceived as mutually exclusive categories of works, operating in distinct ways: if Western works looked more appealing on aesthetic grounds, Byzantine icons were still considered particularly efficacious for private devotional practices. Not surprisingly, alla greca icons became widespread in this period not only in Venice - where domestic interiors were replete with ancone and anconette - but also in many more Western European regions, from Spain through to Flanders. ${ }^{23}$ The success of icons as devotional objects destined for homes was largely responsible for the proliferation and economic success of the specialised ateliers in Candia, where most of such objects were produced for export. ${ }^{24} \mathrm{~A}$ German pilgrim who visited Crete in 1480 was excited to see that

21 Cennini Cennino, Il libro dell'arte, ed. F. Frezzato (Vicenza: 2004) 63; Boccaccio Giovanni, Decameron, ed. V. Branca (Turin: 1992) 738. On Boccaccio's use of Giotto as a metaphor for poets and literati see most recently Eisner M., Boccaccio and the Invention of Italian Literature. Dante, Petrarch, Cavalcanti, and the Authority of the Vernacular (Cambridge: 2013) 109-110; in general on the passage and its interpretation cf. Schwarz M.V. - Theis P., Giottus Pictor (Vienna: 2004-2008) vol. I, 70-76.

22 Ingenerio Andrea, Legenda miracolorum Beatae Virginis et Martyris Theodosiae, ed. F. Corner, Ecclesiae Venetae antiquis monumentis nunc etiam primum editis illustratae ac in decades distributae (Venice, typis Jo. Baptistae Pasquali: 1749) vol. 2, 330-337.

23 Crouzet-Pavan É., "Sopra le acque salse". Espaces, pouvoir et société à Venise à la fin du Moyen Âge (Rome: 1992) 650.

24 Chatzidaki N., Da Candia a Venezia. Icone greche in Italia XV-XVI secolo (Palaio Psychiko: 1993); Cormack R., Painting the Soul: Icons, Death Masks and Shrouds (London: 1997) 167-217; Lymberopoulou A., "Audiences and Markets for Cretan Icons", 
the images one could buy in the workshops of Candia conformed to the most sacred form established by the Evangelist Luke. ${ }^{25}$ Icons were also common in Venetian houses on the island, as it is indicated by the odd story told by the Swiss pilgrim Peter Villinger in the 156os: according to this author, when the Latin clergy of Candia became aware that two men beyond suspicion, namely a doctor and a school teacher, were secretly propagating Calvinistic doctrines, the Bishop gave orders that an icon of the Virgin and Child was to be set on display in all private dwellings, so that there may be no doubt as to the Catholic orthodoxy of their owners. ${ }^{26}$

It is worth stressing that a more definitely Byzantine style was especially associated with Marian images. Icons of Our Lady were often perceived as sites of miraculous agency and, indeed, many of them underwent a shift of status, from domestic to public, after they were officially recognized as miracle-working objects. Many of the Madonnas worshipped in Italian churches since the early modern era are known to have been originally preserved in domestic settings, a well-known example being the Our Lady of Perpetual Help - de Perpetuo Succursu - preserved today in the Roman church of Sant'Alfonso all'Esquilino [Fig. 11.5]. The image is a Cretan icon, displaying the Virgin and Child according to the type of the Panagia tou Pathous as worked out by Andreas Ritzos and his workshop in the second half of the fifteenth century. It was said to have been stolen from a Cretan church by a merchant who set it up in his bedroom in Rome. In several dreams, Mary herself appeared and declared herself disappointed that this most honourable image was being kept in an unseemly place. Mary even threatened the painting's owners with death if they refused to transfer the icon to a church; three people lost their lives before one of them finally resolved to do so, albeit reluctantly:

in Woods K.W. - Richardson C.M. - Lymberopoulou A. (eds.), Viewing Renaissance Art (New Haven-London: 2007) 170-206; Vassilaki M., The Painter Angelos and Icon-Painting

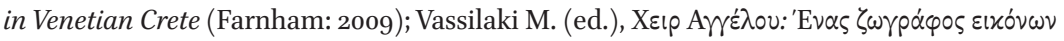

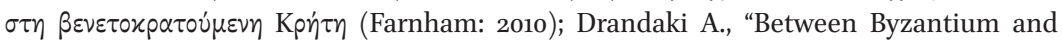
Venice: Icon Painting in Venetian Crete in the Fifteenth and Sixteenth Centuries", in Drandaki A. (ed.), The Origins of El Greco: Icon Painting in Venetian Crete (New York: 2009) 11-18; Newall D., "Candia and Post-Byzantine Icons in Late Fifteenth-Century Europe", in Lymberopoulou A. - Duits R. (eds.), Byzantine Art and Renaissance Europe (Farnham: 2013) 101-134.

25 Fabri Felix, Evagatorium in Terrae Sanctae, Arabiae et Egypti peregrinationem, ed. K.D. Hassler (Stuttgart: 1843-1849) vol. III, 289.

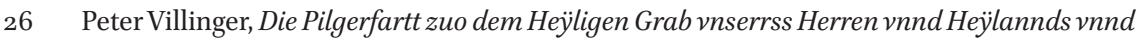
Sälligmachers Jesu Christi, ed. J. Schmid, Luzerner und innerschweizer Pilgerreisen zum Heiligen Grab in Jerusalem vom 15. bis 17. Jahrhundert (Luzern: 1957) 257-325, esp. 321. 


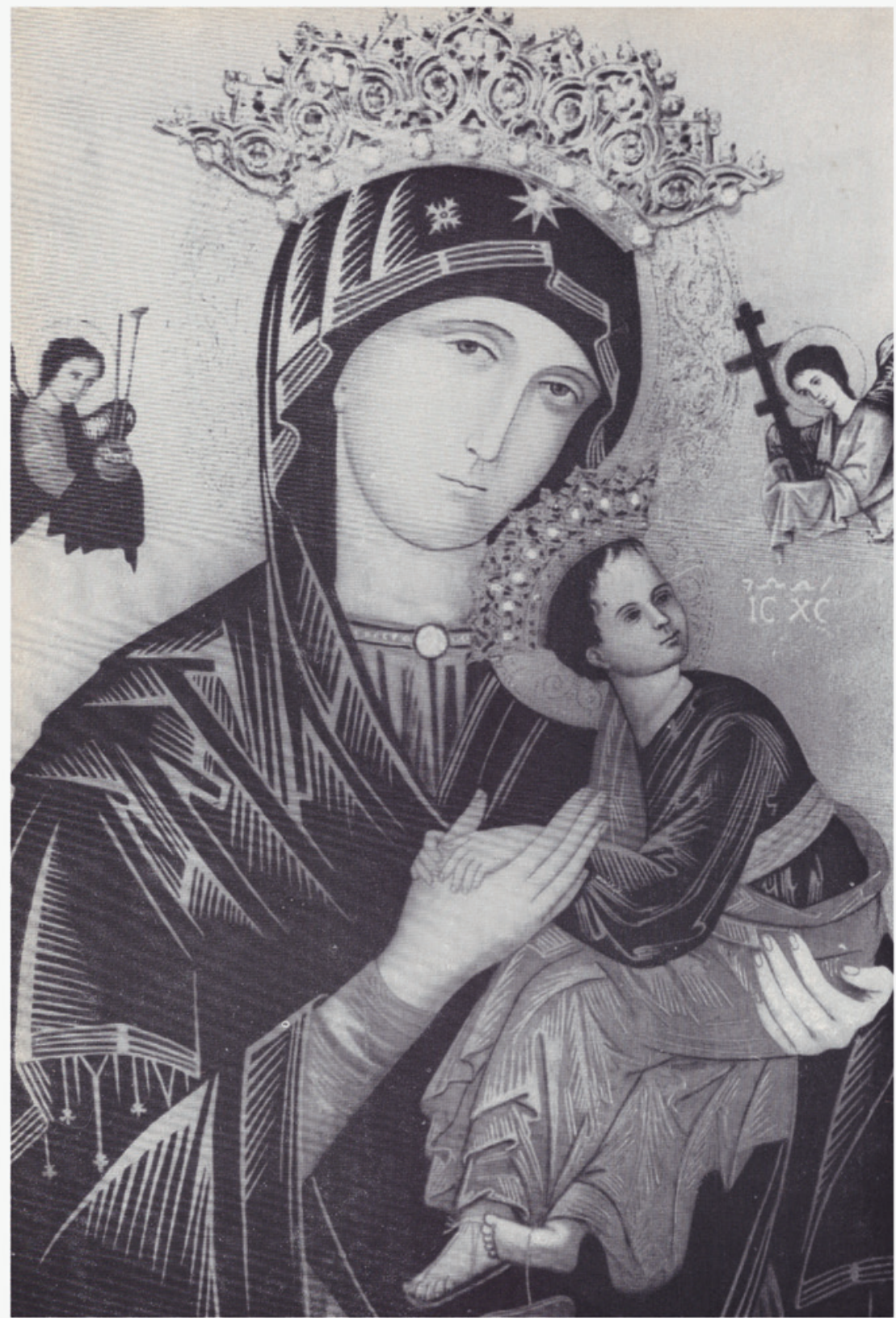

FIgURE 11.5 Andreas Ritzos, Mater de Perpetuo Succursu, ca. 1450, repainted in 1866.

Rome, Sant'Alfonso all'Esquilino

PHOTO: AFTER DE JONGHE M., ROMA SANTUARIO MARIANO, ROME 1969,

FIG. 109 
I am not an infidel but a Christian', said the wife of the second owner, a Roman lady, 'and besides, we are not the only ones who keep a picture like this one in their house: in fact, no Christian is of so evil a life as not to have a picture of this kind in his house. ${ }^{27}$

A recent study has emphasised that small panels intended for domestic settings were often characterised by a relatively free combination of iconographic motifs. Their basic aim was to satisfy their owners' cultic orientations: saints, for example, were selected according to individual criteria, such as their involvement in the family's practice of prayer and their specific association with a member of the household. Even if the aim was to provide their owners with diminutive, portable altarpieces, their compositional program could look much less coherent in its multifarious combination of half - and full-length figures with narrative cycles and isolated episodes. ${ }^{28}$ Iconic images in the central position of a triptych could be substituted for single scenes, for example, and a number of both diptychs and horizontal panels of rectangular shape, mostly produced in Venice, displayed only narrative cycles (as is best shown by an early 14th century panel sold at Christie's in 1995 and an analogous, contemporary painting in Berlin). ${ }^{29}$ The personalisation of religious imagery could here go so far as to transform the traditional juxtaposition of holy persons into a visual dialogue, which, in its aim to suit the donor's specific devotional needs, gave shape to often idiosyncratic compositional and thematic solutions. ${ }^{30}$

27 Quotation after the Latin historical tablet that hung within the church until 1798, as translated by Seidel C.A., The Story of Perpetual Help (New York: 1936) 17. On the Madonna cf. Henze C., Mater de perpetuo succursu: prodigiosae iconis Marialis ita nuncupatae monographia (Rome: 1926).

28 Schmidt V., Painted Piety. Panel Paintings for Personal Devotion in Tuscany 1250-1400 (Florence: 2005) 169-204.

29 Important and Fine Old Master Pictures, sale catalogue, Christie's, London, 8 December 1995, 104-105; Meschede P., Bilderzählungen in der Kölnischen Malerei des 14. und 15. Jahrhunderts. Eine Untersuchung zum Bildtypus und zur Funktion (Paderborn: 1994) 103-108; Seiler P., "Duccio's Maestà: The Function of the Scenes from the Life of Christ on the Reverse of the Altarpiece: A New Hypothesis", in Schmidt V.M. (ed.), Italian Panel Paintings of the Duecento and Trecento (New Haven-London: 2002) 251-277. On the topic

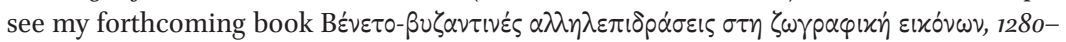
1450 (Veneto-Byzantine Interactions in Icon Painting, 1280-1450), to be published in the M $\eta^{\prime} \mu \eta \mathrm{M} \alpha \nu \dot{\partial} \lambda \eta \mathrm{X} \alpha \tau \zeta \eta \delta \dot{\alpha} \alpha \eta$ series of the Academy of Athens.

Schmidt, Painted Piety 107-140. 
This self-assured, sometimes even shameless approach to traditional iconography was not infrequently complemented by a rather free combination of forms and styles of different origins. A number of objects which can be regarded as works of Greek artists painting for Latin donors in Venice indicate that devotional panels could easily include elements associated with both Byzantine and Western tradition: a painted panel from ca. 1370 now in the Rijksmuseum in Amsterdam [Fig. 11.6], for example, indicates its association with Italy by its gabled shape, which was common for the small devotional triptychs produced in several Italian towns, and the two-registered representation of a Crucifixion combined with a Virgin and Child, which visually hinted at Christ's sacrifice on the cross as the achievement of the Son of God's Incarnation and invited viewers to meditate on this event as the true way to redemption from sin. Thought for a long time to be Venetian, this work indicates its association with a distinctively Palaiologan style - as is best revealed by the modelling technique, the figures' bodily proportions, and chromatic palette - and seems therefore to imply a Byzantine author. Yet, the Virgin Mary is clad with a maphorion decorated with French lilies and wears a white veil, whose right edge terminates in a long strip thrown over Mary's shoulder - all such details point to the artist's acquaintance with formulas rooted in fourteenth-century Italian painting. ${ }^{31}$

This is just one of several cases in which the repertory of forms of Byzantine painting is associated with Italianate features in a single work. It bears witness to the perception of such forms as not mutually exclusive, but at the same time it would be misleading to describe it as 'hybrid': different solutions may indeed coexist in the same object, but they are normally used in a definitely selective way. ${ }^{32}$ Indeed, the dynamics by which a specific motif originally associated with other people's artistic traditions comes to be variously appropriated, reused, modified, reshaped, and invested with new meanings may be connected with a multiplicity of factors. These include the authoritativeness attributed to some images, the communicative efficacy attributed to some forms, their being more or less familiar to other groups and their adaptability to different visual contexts.

Cretan imagery enables us to meditate on such dynamics, even if they are far from being clear-cut. At least from the fifteenth century but probably also earlier, the pictorial workshops of Candia specialised in the production of works

31 Bacci M., "Some Thoughts on Greco-Venetian Artistic Interactions in the Fourteenth and Early-Fifteenth Centuries", in Eastmond A. - James L. (eds.), Wonderful Things: Byzantium Through Its Art (Farnham: 2013) 203-227, esp. 220.

32 Further discussion in Bacci M., "Veneto-Byzantine 'Hybrids': Towards a Reassessment", Studies in Iconography 35 (2014) 73-106. 


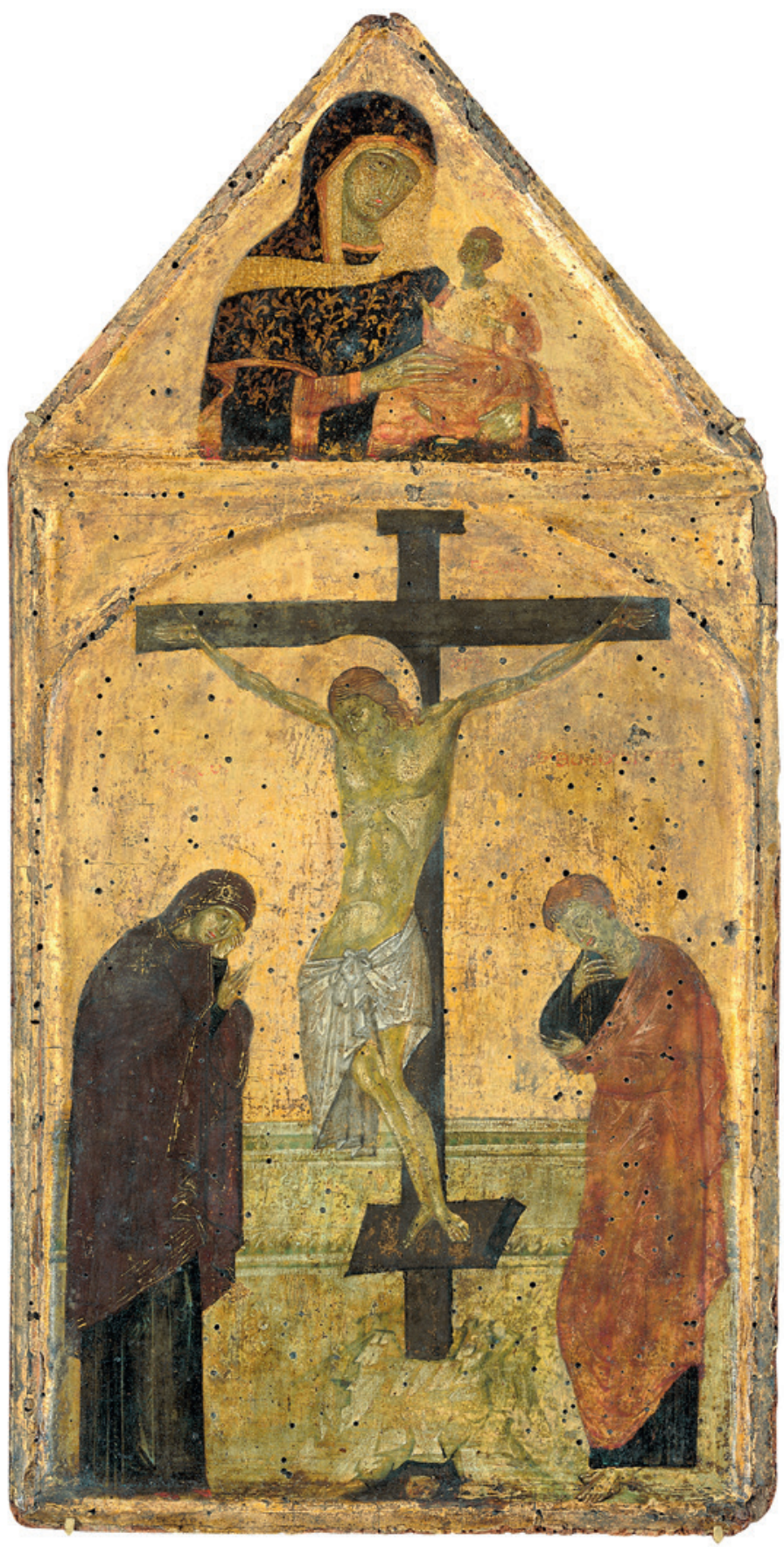

FIGURE 11.6 Byzantine painter, Crucifixion and the Virgin with Child, painted panel, ca. 1370. Amsterdam, Rijksmuseum (C) RIJKSMUSEUM, AMSTERDAM 
made according to either Byzantine or Italian conventions, and meant for either a Venetian or Greek audience. Documentary evidence makes clear that morphologically different pictorial objects, such as altarpieces and large-scale icons, could be produced in the same ateliers and meant for a use in a Latin or Byzantine-rite church, and that, accordingly, they could display forms associated with distinctively Western or Eastern pictorial traditions. ${ }^{33}$ In contrast, in the case of small paintings intended to be used in a domestic setting to suit a small group's or an individual's devotional needs, the displayed imagery usually offers no clear clues as to the religious affiliation of the beholders they were originally meant for. In many cases, there was no stylistic or iconographic divide to prevent painters and their donors from combining schemes of different origins in the same work. In general terms, it can be remarked that a number of works produced on Crete and other Levantine territories during the late 14th and 15th centuries increasingly displayed narrative themes inspired by Italian models, especially Passion scenes rendered in such a way as to lay special emphasis on the more dramatic aspects of Christ's death on the Cross. It can be assumed that the introduction of such solutions was meant to suit a trans-confessional interest in fostering the viewer's empathy for and meditational involvement in the Son of God's sacrifice. ${ }^{34}$

In contrast, painters and their donors tended to privilege Byzantine conventions when they gave shape to images of universal saints, consecrated by a centuries-old visual tradition and associated with distinctively "iconic" formulas. Nevertheless, there were some exceptions to this rule. A very small triptych from ca. 1460 now in the National Gallery of Prague [Fig. 11.7] is a case in point, as it reveals the use of distinctive styles to characterise the saints. ${ }^{35}$ Saint

33 The clearest evidence is provided by a 1499 document first published by Cattapan M., "Nuovi elenchi e documenti dei pittori in Creta dal 1300 al 1500", Thesaurismata 9 (1972) 202-235, esp. 211-212, where mention is made of a large number of images in forma alla greca and in forma alla latina to be painted in the same workshop of Candia. In scholarship, the two expressions are usually interpreted as hinting at a stylistic, Byzantine $v s$ Italian, divide, according to the interpretation first proposed by Chatzidakis, M., "Les débuts de

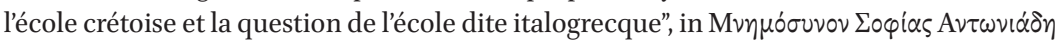
(Venice: 1974) 169-211 [republished in idem, Études sur la peinture postbyzantine (London: 1976), essay n. Iv]. For critical approaches to this interpretation cf. Gratziou O., "A la la-

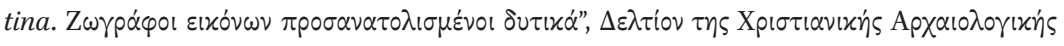

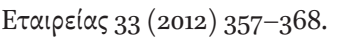

34 Bacci, "Veneto-Byzantine 'Hybrids"” 86.

35 Hlavácková H., "An Unknown Italo-Cretan Triptych from the Former Figdor Collection, now Held in the National Gallery in Prague", Byzantinoslavica 56 (1993) 713-719; Bacci M., "The Holy Name of Jesus in Venetian-Ruled Crete', Convivium 1 (2014) 190-205, esp. 194; Ritzerfeld U., "In the Name of Jesus. The 'HIS'-Panel from Andreas Ritzos and the Christian Kabbalah in Renaissance Crete", Journal of Transcultural Medieval Studies 2 (2015) 245273, esp. 247-249. 


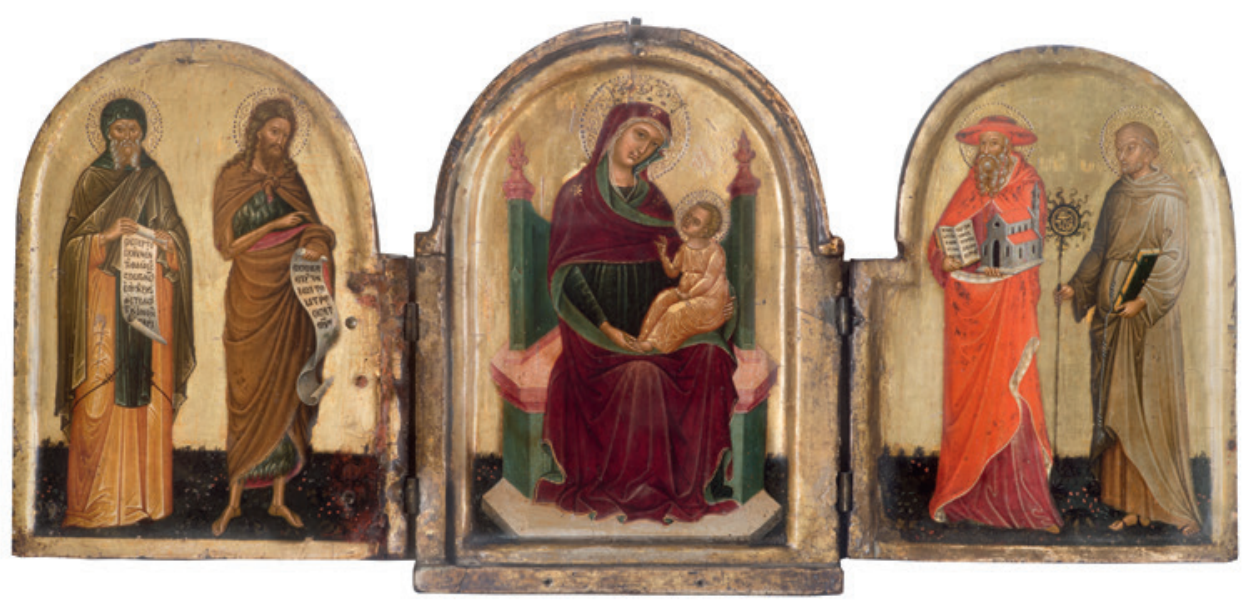

FIGURE 11.7 Cretan painter, Virgin and Child with Sts Anthony the Great, John the Baptist, Jerome, and Bernardine of Siena, painted triptych, ca. 146o. Prague, National Gallery

(C) NATiONAL GALlery, PRAgUE

Anthony the Great, on the left wing, is by far the most 'Greek' in character: as an Eastern saint, having a long iconographic tradition in Byzantine art, he is represented in his standard monastic habit, with black koukoulion and a brown mantle. Accordingly, he wears a long bifurcate beard and is the only figure to be represented in frontal pose. The Greek text inscribed on the white scroll he holds in his hands adds to his characterisation as an oriental saint.

The other figures display features revealing the deliberate appropriation of Italian tradition. The images of Saint Jerome, clad as a cardinal and holding a church model, and Saint Bernardino of Siena holding a staff with the Holy Name of Jesus within a sun disk are in keeping with contemporary Italian iconography. Even if their faces reveal recourse to conventions rooted in Byzantine tradition, their garments, with their elegantly curling folds, hint at Late Gothic forms widely employed in the works of Paolo and Lorenzo Veneziano and their followers. ${ }^{36}$ In this respect, the Prague triptych is perfectly in keeping with contemporary praxis in the ateliers of Candia, where Western saints were frequently depicted in a westernising style. Not surprisingly, Jerome's face is almost identical with that depicted in a mid-fifteenth century Cretan icon now

$3^{6}$ For some comparanda, cf. Flores d'Arcais F. - Gentili G. (eds.), Il Trecento adriatico. Paolo Veneziano e la pittura tra Oriente e Occidente (Milan: 2002) 146-147, 156-157, 228; Pedrocco F., Paolo Veneziano (Milan: 2003) 170-171, 174-175; Guarnieri C., Lorenzo Veneziano (Milan: 2006) 113, 168, 176, 201, 212. 
in the Fitzwilliam Museum in Cambridge. ${ }^{37}$ In turn, the Virgin Mary is shown seated on a green throne which perfectly compares with the type used by the painter Angelos in an icon now in the Zakynthos Museum. ${ }^{38}$

In many respects, the use of Italianate forms was linked to specific iconographies which were associated with Italian models. This is particularly true of those saints who were not worshipped in the Orthodox tradition and even more so of newly canonised members of the Franciscan order, as in the case of Saint Bernardino. In order to represent such figures, Greek artists could not rely on their traditional repertory of forms and it is logical that they turned to Italian artworks as sources of inspiration. But there is obviously more to this: a strong iconographic tradition shaped the representation of the Mother of God in Byzantium; yet nevertheless occasionally Cretan painters working on new images of Mary borrowed suggestions from Italian art.

The Prague triptych insists on Mary's role as Queen of Heaven by representing her wearing a Gothic crown and an elegant, mantle-like, green silk-lined maphorion. The Virgin's maternal nature is emphasised by the bent pose of her head, leaning toward her Son, yet glancing directly at the viewer. The Italianate flavour seems to be introduced as a visual strategy to stress the Mother's intimate relationship with both her Child and the beholder. Equally Italianate is the attempt at involving the figures in a mutual dialogue. The saints engaging in mute communication with the Virgin are also those represented according to Western stylistic and iconographic patterns. Unlike the frontally displayed, 'Byzantine' Anthony, John the Baptist turns towards Mary and Christ and interacts with them, so creating a visual pendant to the two interceding saints on the right wing. Mirroring them, he is provided with a Gothicising posture, elegantly traced folds, and a gently curling scroll, whose sinuous silhouette stands at odds with the much more regular parchment held by Saint Anthony. All of the figures are represented standing on a flowery meadow, which is reminiscent of Late Gothic imagery.

The use of distinctive visual aspects, associated with either Byzantine and Western traditions, in a single work can be attributed to the need to satisfy

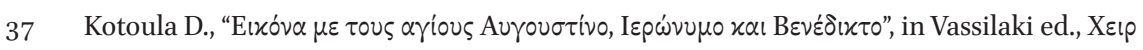

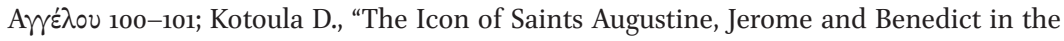
Fitzwilliam Museum at Cambridge: Theme and Function", in Vassilaki M. (ed.), Studies on

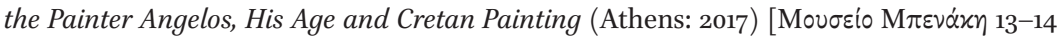
(2013-2014)] 129-143.

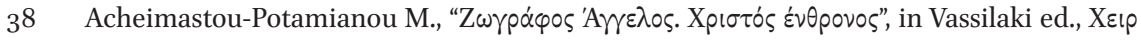
Aүŕ̀ं ou 196-197. 
specific devotional needs. In this work, the icon-like image of Anthony, made in the Greek way, is offered to the viewer's prayers as an object of contemplation, for he does not interact at all with nearby figures. The other Italianate saints renounce their structural fixity with the aim of staging an efficacious supplication on behalf of the soul of the viewer. The desire to see one's intercessors actively engaging in the promotion of one's spiritual health transcended the confessional divide and could be easily appropriated by Orthodox believers. This fact, much more than any aesthetic appreciation of Italian arts, paved the way for the selective appropriation of Westernising devices in panels meant for devotional and domestic use.

\section{Select Bibliography}

Bacci M., "Pisa bizantina. Alle origini del culto delle icone in Toscana", in Calderoni Masetti A.R. - Dufour Bozzo C. - Wolf G. (eds.), Intorno al Sacro Volto. Genova, Bisanzio e il Mediterraneo (secoliXI-XIV) (Venice: 2007) 63-78.

Bacci M., "Some Thoughts on Greco-Venetian Artistic Interactions in the Fourteenth and Early-Fifteenth Centuries", in Eastmond A. - James L. (eds.), Wonderful Things: Byzantium Through Its Art (Farnham: 2013) 203-227.

Bacci M., "Veneto-Byzantine 'Hybrids':Towards a Reassessment", Studies in Iconography 35 (2014) 73-106.

Belting H., Bild und Kult. Eine Geschichte des Bildes vor dem Zeitalter der Kunst (Munich: 1990).

Cannon J., Religious Poverty, Visual Riches. Art in the Dominican Churches of Central Italy in the Thirteenth and Fourteenth Centuries (New Haven-London: 2013) 63-64.

Cormack R., Painting the Soul: Icons, Death Masks and Shrouds (London: 1997).

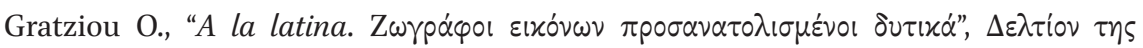

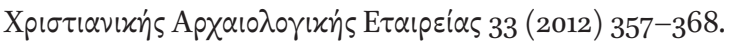

Lymberopoulou A., "Audiences and Markets for Cretan Icons", in Woods K.W. Richardson C.M. - Lymberopoulou A. (eds.), Viewing Renaissance Art (New HavenLondon: 2007) 170-206.

Matthews Th. F., "Early Icons of the Holy Monastery of Saint Catherine at Sinai", in Nelson R.S. - Collins K.M. (eds.), Holy Image - Hallowed Ground. Icons from Sinai (Los Angeles: 2006) 39-55.

Matthews Th. F., The Dawn of Christian Art in Panel Paintings and Icons (Los Angeles: 2016).

Meschede P., Bilderzählungen in der Kölnischen Malerei des 14. und 15. Jahrhunderts. Eine Untersuchung zum Bildtypus und zur Funktion (Paderborn: 1994). 
Newall D., "Candia and Post-Byzantine Icons in Late Fifteenth-Century Europe", in Lymberopoulou A. - Duits R. (eds.), Byzantine Art and Renaissance Europe (Farnham: 2013) 101-134.

Schmidt V., Painted Piety. Panel Paintings for Personal Devotion in Tuscany 1250-1400 (Florence: 2005).

Totev T., The Ceramic Icon in Medieval Bulgaria (Sofia: 1999).

Vokotopoulos P., "Funzioni e tipologia delle icone", in Velmans T. (ed.), Il viaggio dell'icona dalle origini alla caduta di Bisanzio (Milan: 2002) 109-150. 